\title{
Entrelacs
}

Cinéma et audiovisuel

HS | 2012

Le post-humain et les enjeux du sujet

\section{L'entre-deux du corps extrême : post-humain ou trop humain}

Simone Sausse

\section{(2) OpenEdition}

Journals

Édition électronique

URL : http://journals.openedition.org/entrelacs/313

DOI : 10.4000/entrelacs.313

ISSN : 2261-5482

Éditeur

Éditions Téraèdre

Édition imprimée

Date de publication : 2 février 2012

ISBN : 978-2296567177

ISSN : 1266-7188

\section{Référence électronique}

Simone Sausse, "L'entre-deux du corps extrême : post-humain ou trop humain », Entrelacs [En ligne], HS | 2012, mis en ligne le 01 août 2012, consulté le 21 avril 2019. URL : http:// journals.openedition.org/entrelacs/313; DOI : 10.4000/entrelacs.313

Ce document a été généré automatiquement le 21 avril 2019

Tous droits réservés 


\title{
L'entre-deux du corps extrême : post-humain ou trop humain
}

\author{
Simone Sausse
}

Le texte complet de cet article est publié dans l'ouvrage :

Post humain et les enjeux du sujet

Editeur : L'HARMATTAN (2 février 2012)

Collection Ouverture Philosophique

ISBN-10 : 2296567177

ISBN-13 : 978-2296567177

\section{RÉSUMÉS}

L'auteur propose de montrer en quoi le post-humain correspond à un entre-deux, à partir des situations cliniques de "corps extrêmes » (corps handicapé, corps du grand prématuré, corps blessé, corps du grand brûlé, corps du vieillard, corps transsexuel, corps malade...), qui ont en commun de conduire aux frontières de l'humain, et des démarches artistiques contemporaines, qui explorent aussi les virtualités corporelles post-humaines. En actualisant les enjeux du sujet, on interrogera la question du post-humain, orientée tantôt vers l'inhumain, l'animal, la déshumanisation, tantôt vers une nouvelle péripétie de l'humain, où ce qui est désigné comme inhumain est au contraire trop humain. 


\section{AUTEUR}

\section{SIMONE SAUSSE}

Maître de conférences, Université Denis Diderot, Paris 7, Membre de la Société Psychanalytique de Paris 